\title{
Assessing the US Congress
}

I have wondered at times what the Ten Commandments would have looked like if Moses had run them through the US Congress. (President Ronald W. Reagan)

At first glance, while the nation of the United States of America has changed greatly since the Constitution was written in 1787 , the political system has remained remarkably stable. The United States is still a federal system, with its government based on the separation of the executive, legislative and judicial powers. Congress, the legislative branch of the government, remains a bicameral body, with the differences between its two chambers based upon the principles laid down by the Founding Fathers. However, further investigation of the American political establishment at the beginning of the twenty-first century reveals some significant changes. The role of the federal government has been transformed; it now reaches into every area of American life requiring Congress to deal with issues as diverse as taxation, space exploration, gun control and the ethics of cloning. The presidency has claimed for itself a much greater part in the initiation of legislation than the Founding Fathers ever would have imagined. Congress has been forced to respond to this new 
challenge along with other changes such as the increase in interest-group activity, the importance of money within the political system, the development of mass communication and the establishment of primary elections as the first step towards securing a seat in the House of Representatives or Senate.

It is possible to argue that the way in which the Constitution has been able to adapt to such changes without the need for significant amendment, is a triumph for the American political structure. However, it could also be argued that many of the difficulties faced by the United States in the new century will not be solved easily using eighteenth-century institutions. Such a view resonates with President Reagan's famous assertion that the growth of federal power since 1933 has led to a situation where 'government is not the solution to our problem; government is the problem'.

For any student of the US Congress this is a difficult but important issue. It is also one which the American public has no consistent view on. Opinion polls in 1990 suggested that Congress was failing in its task; when the public was asked whether they approved of the way Congress was doing its job, the highest positive response rate gained in that year was 28 per cent, with 65 per cent disapproving and 7 per cent expressing no opinion. ${ }^{1}$ It was to take until January 1999 for Congress's approval rating to reach over 50 per cent. In recent years, however, the poll results have been much more encouraging, with public approval hitting a high of 84 per cent in October of 2001. While this extraordinary high result can be attributed to the aftermath of the terrorist attacks on New York and Washington DC (the previous month produced an approval score of 42 per cent), since early 2000, Congress has been consistently receiving higher approval than disapproval ratings. 
Opinion polls are a good snapshot of the public mood at one time, but as the results from November 2001 show, they can be influenced by a variety of factors. The problematic question of whether Congress 'works' is, though, an important one. This chapter will examine that question by considering some of the challenges faced by the modern Congress.

\section{Gridlock}

The term gridlock became popular in the 1980s. Originally used to describe standstill in New York City traffic jams, it was soon adopted by political journalists to refer to an inability by Congress and/or the President to enact new legislation, even if there was seemingly a majority in favour of action. The reasons for gridlock occurring in the political system are plentiful. The Founding Fathers must take their fair share of the blame (or credit, depending on your view). The system of checks and balances, designed to prevent the rise of a despotic government, can also make legislating a difficult task. With the agreement of the House, Senate and the President needed for a bill to become a law (the exception being when Congress overrides a presidential veto), any one of those bodies can prevent a law being enacted. The most extreme example of this in recent years was the stand-off between Congress and White House in 1995 over the budget which led to a government shutdown. Compromises between the branches of government are hard fought and often difficult to achieve.

It can be argued that such disagreements between the President and Congress have increased in recent years because of the tendency towards divided government - where different parties control the executive and legislative branches of government. Between 1969 and 2001, divided government 
was in place for all but six years. With different policy agendas being pursued by the White House and Congress, it is perhaps not surprising that gridlock occurs. However, this explanation is not enough by itself. Even when the same party has controlled both branches of government, this has not meant that the difficulties inherent in passing legislation have disappeared. Indeed, Democrat Presidents Carter and Clinton both faced problems with achieving their legislative goals even when the Democrats were in charge of Congress.

Congress itself can contribute to problems of gridlock. The gate-keeping function of Congressional committees provides a large barrier to action at the very beginning of the legislative process in both the House of Representatives and the Senate. Additionally, the lack of sanctions available to the party leaders to force members to behave or vote in a particular way make any form of party government near impossible. As Newt Gingrich discovered while attempting to pass the measures included in the Contract with America, the bicameral structure of Congress can cause problems. Even when one chamber votes in favour of legislation, there is no guarantee that their colleagues on the other side of Congress will do likewise.

Interest groups have also been blamed for Congressional inaction. Advocates of healthcare reform regularly point to the money donated to Congressional candidates by health insurance companies as a major factor in Congress's failure to pass comprehensive healthcare legislation. The same arguments are made by those frustrated by the reluctance of Congress to pass further restrictions on the ownership of guns. The contention is that the nature of the legislative process makes it easy for members to block the progress of new laws, especially by those on the appropriate committee, without drawing public attention to their actions. Consequently, while 
interest groups may find it difficult to persuade Congress to pass new laws, they are far more successful in using their influence to prevent the passage of legislation.

While gridlock has on occasions been a feature in modern American Government, the extent of the problem should not be overstated. In recent periods of divided government, pieces of major legislation have been successfully passed, often through compromise between Congress and the presidency. To characterise gridlock as a constant feature of the US political system would be just as erroneous as to deny that it exists at all. Even when gridlock does prevent Congress from passing legislation, this does not automatically lead to the conclusion that it is failing in its job as the federal legislature. It could be argued that the point of the checks and balances is to ensure that laws are not made casually; that it is right that it is easier to block a law than to pass one. This is partly a subjective matter, as former Senate Republican leader and Presidential nominee Bob Dole commented, 'if you're against something you'd better hope there is a little gridlock'. It is also a function of the designs of the Founding Fathers and their concern to prevent an overpowerful government. There is a case to be made that the federal system was designed to make it difficult to pass legislation and that gridlock is evidence that the government is working as it should.

\section{The making of coherent policy}

One further accusation against Congress is that it is unable of passing a coherent policy programme in the interests of the national good. This was touched on in chapter 2 . This argument is a function of two features of Congress: the re-election impulse of members and the power of the committee. With 
members focused throughout their term of office on the need for re-election, the interests and preferences of their constituents will be a priority. Representatives and Senators will behave and take positions in order to benefit their voters and, if possible, ensure that the benefits of legislation are targeted at their constituency. The committee system allows members to specialise in issues of concern or potential benefit to their constituents and exercise a great deal of influence over those areas of policy due to the position of the committee in the legislative process. The result of this, critics argue, is a system of policy making which is directed at parochial concerns rather than any greater national need.

As argued before, the whole notion of 'the national good' is a subjective one. When subsidies for farmers are passed by the Agriculture Committee or funds for a building project benefit the constituency of a member of the Public Works Committee, Congress is accused of legislating in a parochial manner. Those communities who benefited from such Congressional action would, no doubt, contend that the legislation was not only necessary but was evidence of Congress acting in the national interest. It can also be argued that Congress was established as a representative body, and would be failing in its task if members did not work for the benefits of their constituents.

\section{Challenges for the twenty-first century}

One further question to be considered is whether the structure of the legislative process makes Congress able to tackle the issues that will emerge in the new century. It could be argued that a system which appears to make inaction easy to achieve will always be better at sustaining the status quo than 
producing innovative programmes. Congressional policy making can often be characterised as incremental. Programmes are introduced and amended over time as feedback is received about the successes and failures. It is far easier for Congress as a whole and members individually to look to amend existing policies than it is to embark on whole new programmes. This is consistent with the view of Congress as one where power is decentralised, with many hurdles for legislation to cross and dominated by members with re-election uppermost in their minds. However, this can create a problem when entirely new challenges arise or when it becomes clear that the existing approach to a problem is fundamentally inadequate.

\section{Budget deficit}

At the heart of the budget stand-off between President Clinton and the Republican-controlled Congress was the issue of the federal budget deficit. The growth of government spending throughout the post-war period had led to small budget deficits being reported throughout the 1950s and 1960s. The economic picture worsened in the 1970s and the issue of the deficit became prominent in the 1980 presidential election. The election in 1980 of Ronald Reagan with a Republican majority in the Senate, promised for some the opportunity for a more fiscally conservative approach to spending. However, if their policy was to bring the budget back into surplus, they failed completely. By the time Reagan left office in 1989, the deficit had reached $\$ 200$ billion. Critics of the President argued that his policy of cutting taxes while at the same time pushing for large increases in defence spending caused the national debt to escalate. Reagan and his supporters aimed their fire at the inability of the US Congress to relinquish their attachment to spending on pork barrel projects and inefficient 
programmes. Congressional attempts to pass legislation which would force spending down (most notably the 1987 Gramm-Rudman-Hollings Act) proved ineffective and by the time of the 1992 presidential election the budget deficit was only a little short of $\$ 300$ billion.

The state of the economy was to dominate the 1992 election and although some progress was made, when the Republicans took over control of Congress in 1995, the deficit was still in excess of $\$ 150$ billion. Determined to bring the budget into surplus, the Republican majority proposed sweeping cuts in social spending which were to bring Congress into conflict with the Clinton White House and lead to the stand-off which saw the government shutdown for a short period in late 1995. There was even an unsuccessful attempt by Congress to amend the Constitution to force future lawmakers to maintain a balanced budget. However, once again the problem of reducing government outlays and protecting valuable social programmes prevented the US Government from finding a solution to the problem.

Compromise was eventually reached between President Clinton and Congress and in 1998 the Office of Management and Budget reported a surplus for the first time since 1969. The problem, though, has not gone away. A combination of Congress passing the deep tax cuts proposed by President George W. Bush and increases in defence and other spending (partially in a response to the terrorist attacks of 2001, although not exclusively) will lead to budget deficits in 2002, 2003 and 2004.

\section{Social security}

The problem of the budget deficit has an impact on another emerging issue - the future of social security. Through a 
programme established in 1935, all working Americans contribute through payroll taxes to a fund which is used to support retired and disabled citizens and their dependants. The problem which is faced by the government is that due to population growth and longer life expectancy, it is projected that by 2016, benefits will begin outpacing revenues, and by 2038 the surplus will be exhausted entirely.

The solution to this problem is not clear and has caused a certain amount of controversy. Democrats in particular argue that the current system is essentially sound and that only incremental change is necessary. Others, including President George W. Bush are pushing for more fundamental reform. One particular proposal is to create individual social security accounts in which payroll taxes would be invested to provide for future payments. Critics of the scheme argue that investing revenue in stocks could prove risky and that the use of individual accounts would mean a decrease in the level of payments to cover transaction charges.

The future of social security is the sort of problem that Congress must address successfully if it is to be considered an effective legislature. If a fundamentally new approach is indeed necessary, then Congress must prove the stereotype of a legislature dominated by local interests which favours gradual change wrong. As with any law-making body, it must ultimately be judged on its success in tackling the problems which its society faces.

\section{Summary}

Assessing whether Congress 'works' is no easy task. It is difficult to decide on the criteria by which it should be judged. Gridlock is often quoted as evidence of the political 
establishment malfunctioning, however, it could also be argued that the system was designed to make it difficult for laws to be passed. On any one issue, it is a matter of opinion whether the passage of a new law is the desirable course of action. Similarly, while accusations of parochialism are frequently levelled at Congress, it must also function as a representative body and any judgement of what is in the national interest is bound to be subjective. The appropriate criteria with which to judge Congress is perhaps how effectively it can address the challenges which will emerge in the new century.

\section{Notes}

1 All figures taken form Gallup polls conducted from October 1990 to June 2002. 